Radiotherapeutic Centre, Addenbrookes Hospital, distinguished for his work in biophysics and radiotherapy; he has materially contributed to our knowledge of the effects of radiation on metabolic processes.

Prof. A. C. OfFord, professor of mathematics, Birkbeck College, University of London, distinguished for his contributions to Fourier analysis and the theory of integral functions.

Prof. A. G. Pugstey, O.B.E., professor of civil engineering, University of Bristol, distinguished for his contribution to the reliability of aircraft structures, the design of which has been much influenced by his researches.

DR. R. R. RACE, serologist, Medical Research Council, Lister Institute, distinguished for the application of serological methods in human genetics, and of genetics in medicine ; in particular he is principally responsible for the progressive elucidation of the complicated genetical situation found in connexion with the rhesus and other factors capable of causing hæmolytic disease.

Martin Ryle, lecturer in physics, University of Cambridge, distinguished for his leadership of the Cambridge school of radioastronomy.

D. MacL. Sмith, chief engineer, Gas Turbine Department, Metropolitan-Vickers Electrical Co., Itd., distinguished for his contributions to the theory and design of steam and gas turbines and axial flow air compressors, and their applications to aircraft, marine propulsion, the railway locomotive and industrial use.
Prof. F. S. SPRING, professor of organic chemistry in the Royal Technical College, Glasgow, distinguished for research in organic chemistry, particularly in the field of sterols, of triterpene resinols and related acids and of heterocyclic compounds with antibiotic activity.

E. W. TAYLOR, C.B.E., joint managing director of Cooke, Troughton and Simms, Ltd., distinguished for his contributions to the development of optical instruments used in surveying and in phase-contrast microscopy.

Prof. S. Tolansky, professor of physies, Royal Holloway College, University of London, distinguished for his contributions to the fine structure of spectral lines, the determination of nuclear spin, and new types of interference fringes.

Dr. Marthe Vogt, lecturer in pharmacology, University of Edinburgh, distinguished for her work on the quantitative estimation of the cortical hormone in adrenal venous blood, and for her discovery of the various factors which control the output of this hormone.

Prof. T. S. Westoll, professor of geology in the University of Durham, distinguished for his palæontological investigations on Palæozoic fishes and especially on their relationships with the amphibia.

D. D. Woops, reader in microbiology, University of Oxford, distinguished for his contributions to bacterial chemistry and particularly for the explanation of the antibacterial action of sulphonamides; the reversal of this action by para-amino-benzoic acid is a contribution of fundamental importance.

\section{University of Manchester}

THE status of professor of mathematical analysis has been granted to Dr. Kurt Mahler, reader in mathematics in the University.

Among the honorary degrees to be conferred on May 21, those of D.Sc. have been awarded to Dr. W. Lawrence Balls, the authority on cotton, and Prof. A. von Muralt, the physiologist.

\section{Royal Society's Depository of Unpublished Mathe- matical Tables}

Following the decision of the Royal Society to open a depository for unpublished mathematical tables (see Nature, 167, 303; 1951), the following tables have been accepted: "Tables for the Plethysm of S-Function", by E. M. Ibrahim; "Sines and Cosines of the Decimal Circle", by the Raytheon Manufacturing Co.; "Table de Factorisation des Nombres $2 N^{2}+1$ ", by A. Gloden; "Tables of Fresnel Integrals, Modified Fresnel Integrals, the Probability Integral, and Dawson's Integral", by M. S. Corrington; "Tables des Solutions des Congruences $X^{2^{n}}+1 \equiv 0(\bmod p), n=4,5,6, p<10^{4}$ ", by A. Gloden; "Tables of $\int_{0}^{a} I_{0}(a) \mathrm{d} a$ and $\int_{a}^{\infty} K_{0}(a) \mathrm{d} a$ ", by C. Mack and Miss M. Castle; and "Chebyshev Polynomials : Exact Values", by J. C. P. Miller, C. W. Tones, J. F. C. Conn and R. C. Pankhurst. These tables can be consulted in the library of the Royal Society, and photo-copies can be prepared at the expense of those who desire them. Offers of

\section{nd VIEW S}

tables for the depository should be addressed to the Assistant Secretary, Royal Society, Burlington House, Piccadilly, London, W.1.

\section{World Federation of Scientific Workers}

THE World Federation of Scientific Workers had proposed to hold a meeting of its Executive Council at Madingley Hall, Cambridge, during March 22 and 23 ; the Federation was informed by the Home Secretary, however, that no foreign members of the Council would be granted visas or allowed to enter Britain to attend the meeting, which has therefore been abandoned. The World Federation of Scientific Workers consists of sixteen organizations of scientific workers from fourteen countries, including Britain, the United States, the U.S.S.R., China, France and India. It was founded six years ago on the initiative of the Association of Scientific Workers in Great Britain, and is one of the non-governmental international organizations recognized by the United Nations. The World Federation is governed by a general assembly, which meets every two years, decides policy, and elects the chief officers and an Executive Council. There are twenty-two places in the Council, of which sixteen are occupied and six are to be filled. The present officers are: President, Prof. F. Joliot-Curie ; Vice-Presidents, Prof. J. D. Bernal, Prof. C. F. Powell, Prof. Li-Tze-Kwang and Prof. Linus Pauling; Treasurer, Dr. W. A. Wooster ; Secretary-General, Mr. J. G. Crowther (15 Half Moon Street, London, W.1). Since the foundation of the World Federation in London in 1946, the Executive 